\title{
Use of Fibres Obtained from the Cashew (Anacardium ocidentale, L) and Guava (Psidium guayava) Fruits for Enrichment of Food Products
}

\author{
Maria de Fátima O. Matias, Edson Leandro de Oliveira*, Eduardo Gertrudes and \\ Margarida Maria dos Anjos Magalhães \\ Departamento de Engenharia Química - PPGEQ - CT - Universidade Federal do Rio Grande do Norte; Av. Sen. \\ Salgado Filho, s/n; Campus Universitário; edson@eq.ufrn.br; 59072-970; Natal - RN - Brasil
}

\begin{abstract}
With the purpose of using the cashew and guava dried bagasse for enrichment of cookies, a study of drying process was done. The physico- chemical characterization included the determination of $\mathrm{pH}$, soluble solids, total acidity, protein, lipids, fiber, ash, moisture and total and reducing sugars. Total coli forms, yeasts and molds counting were the microbiological analyses conducted. Enriched cookies were prepared by adding 5, 10 and 15\% (of total weight) of dry residues of cashew and guava. Appearance, color, odor, taste and texture were the sensorial attributes evaluated for the enriched and non-enriched cookies. The granulometric analysis defined that more adequate particle to add were between 65 and 100 mesh. The enriched cookies with cashew and guava fibers in 10\% e 5\%, respectively, showed a high rate of acceptability in relation to flavor.
\end{abstract}

Key words: Fiber, fruit bagasse, guava, cashew

\section{INTRODUCTION}

Presently there has been a worldwide awareness on the use of industrial waste. In the food industry, the term "waste" is used to describe some part of the raw materials not used or rejected during the processing of the main product. In the case of fruit pulp industries, the waste concerns the "bagasse" (fruit residue) obtained during the fruit pulp extraction processing. The market of frozen fruit pulps has soared in the last decades and is being considered a great potential as the dietary habits, regarding in nature fruit consumption tend to be substituted by fruit pulp consumption, thus avoiding various pre-preparation operations (Borges et al., 1999). The increase in fruit pulp consumption generates a greater production of bagasse that is the residue of industrialized fruits, made up of fruit skin, stone or kernel and seeds.

In the seventies, Burkitt et al (1972) drew the hypothesis that a low fiber diet would play an important role in the disease-causing factors in the western countries. Since then research works on this field have showed the various benefits of a rich fiber diet for health preservation and disease prevention. Fibers are also an important ingredient in a nutritional therapy. Based on these discoveries, most professionals involved in food processing as well as those in the medical field have been emphasizing the importance of a rich fiber diet.

\footnotetext{
* Author for correspondence
} 


\section{MATERIALS AND METHODS}

In this study bagasse of red guava (Psidium guayava) and cashew (Anacardium orientale, L), obtained from the waste generated by the fruit pulp industrialization were used (Fig. 1). Fruits harvested from January to June 2002, from the Greater Natal and rural dry area in the State of Rio
Grande do Norte, Brazil provided the bagasse for this study.

In the fruit industries the bagasse were stored in polyethylene bags soon after being crushed for extraction of the fruit juice and then they were stored in a industrial freezer. In the laboratory, they were kept in a freezer at $-18^{\circ} \mathrm{C}$. Before using them for the drying experiments, they were thawed at room temperature.

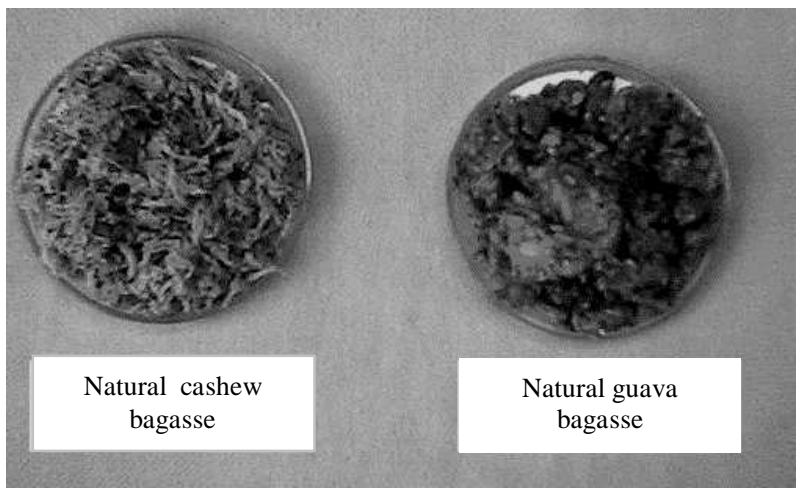

Figure 1 - Natural bagasses of cashew (Anacardium ocidentale, $L$ ) and guava (Psidium guayava).

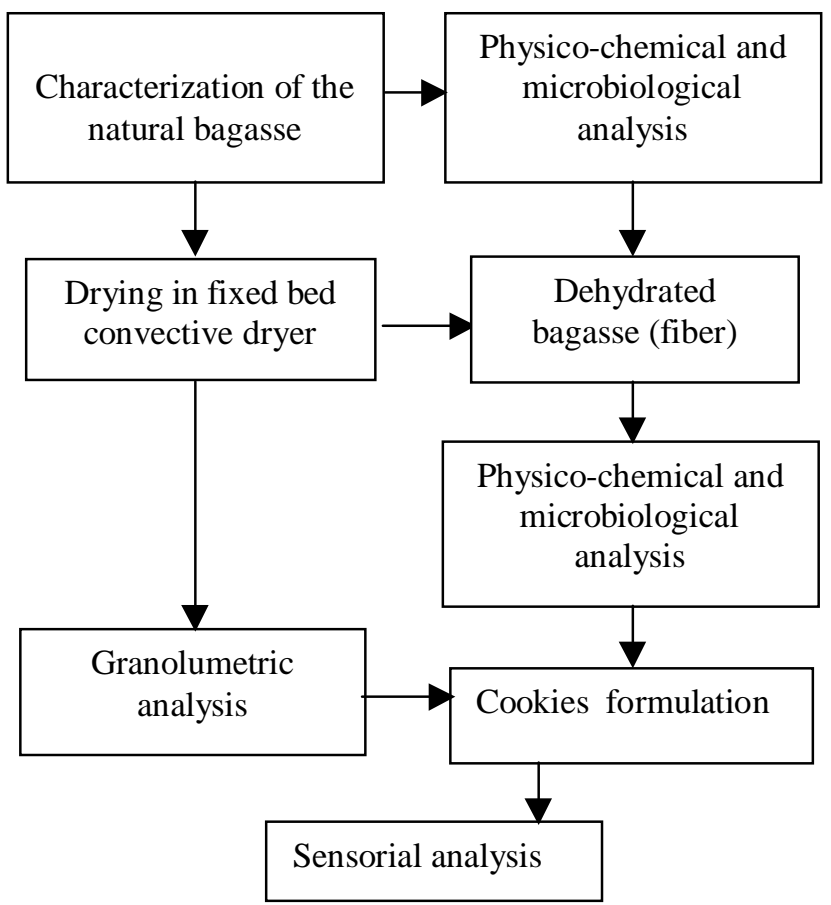

Figure 2 - Flowchart of the experimental procedure for obtaining fiber source. 
Table 1 - Ingredients of the cookies

\begin{tabular}{ll}
\hline Butter & Ingredients \\
Wheat Flour & \\
Sugar & \\
Cashew and guava dehydrated bagasse & \\
\hline
\end{tabular}

The methodology used in this work is described in the flowchart of Fig. 2. The physico-chemical, microbiological and sensorial analysis of the natural and dehydrated bagasse were carried out. These included $\mathrm{pH}$, acidity, soluble solids, proteins, lipids, fibers and ashes, according to the Analytical Standards of the Adolfo Lutz Institute (1985), and reducing sugars and total reducers according to the DNS method. In the microbiological analysis, total coliforms and fecal coliforms were counted, and the amount of mould and yeast was evaluated based on the A.P.H.A. methodology (Speck, 1976). The sensorial attributes of the bagasse analyzed were color, taste and flavor.

The drying processes of the two types of bagasse from cashew and guava were carried out under the following conditions: temperature at $55^{\circ}$ and $65^{\circ} \mathrm{C}$; $1 \mathrm{~cm}$ thickness, and drying air speed of $3.0 \mathrm{~m} / \mathrm{s}$. Both cashew and guava natural bagasse were placed in the dryer (in perforated trays with stainless steel mesh) under quasi-stationary temperature and air speed conditions. The trays were removed from the dryer at 30 minutes interval for weighing and then they were returned to the dryer at different stages (tray 1 was placed at the lower part of the dryer, and tray two was placed above it) with the objective to evaluate the drying process. This procedure was repeated for a period sufficient for the material to attain a constant weight. The products were triturated and stored in specific packages.

The sensorial analysis of the cookies was carried out by a group of 28 non trained judges. The samples with different concentrations of bagasse in their formulation were randomly distributed. The Hedonic Scale Method was used by which the following characteristics were evaluated: appearance, color, odor, taste and texture. The results were statistically analyzed using the Variance Analysis, test F, as well as a multi comparison test -Tukey Test (Teixeira et al., 1978).

\section{RESULTS AND DISCUSSION}

The characteristics of the bagasses obtained from the fruit pulp processing showed variations not only as a function of the ripening of the fruits, but also as a function of the variety of fruits processed. In Tables 2 and 3, the results relating to the sensorial characteristics of the guava and cashew bagasse are shown, respectively.

Table 2 - Sensorial characteristics of the natural guava (Psidium guayava) bagasse

\begin{tabular}{ll}
\hline \multicolumn{1}{c}{ Physical characteristics } & \multicolumn{1}{c}{ Bagasse } \\
\hline Color & Pink \\
Flavor/aroma & Pleasant, typical of guava \\
Components & Seeds and skin \\
Aspect & Paste consistency \\
\hline
\end{tabular}

Table 3 - Sensorial characteristics of natural cashew (anacardium ocidentale, L) bagasse

\begin{tabular}{ll}
\multicolumn{1}{c}{ Physical characteristics } & \multicolumn{1}{c}{ Bagasse } \\
\hline Color & Dark yellow \\
Flavor/aroma & Astringent, typical of the cashew \\
Components & Green unripe cashew \\
Aspect & Fibrous \\
\hline
\end{tabular}


Table 4 - Physico-chemical characterization of natural bagasses of guava (Psidium guayava) and cashew (Anacardium ocidentale, L).

\begin{tabular}{|c|c|c|}
\hline \multirow{2}{*}{ Parameters } & \multicolumn{2}{|c|}{ Natural bagasse } \\
\hline & Guava & Cashew \\
\hline $\mathrm{pH}$ & $3.51 \pm 0.77$ & $4.01 \pm 0.46$ \\
\hline Acidity ( $g$ ac citric/100g of the sample) & $1.59 \pm 1.63$ & $1.34 \pm 1.32$ \\
\hline Soluble solids $\left({ }^{\circ} \mathrm{Brix}\right)$ & $15.4 \pm 0.71$ & $12.0 \pm 0.57$ \\
\hline Reducing sugars (mg/100g) & $13.32 \pm 0.46$ & $6.84 \pm 0.78$ \\
\hline Total sugars $(\mathrm{mg} / 100 \mathrm{~g})$ & $13.42 \pm 0.56$ & $7.68 \pm 0.63$ \\
\hline Proteins $(\%)$ & $1.65 \pm 1.62$ & $1.83 \pm 1.72$ \\
\hline Lipids (\%) & $0.13 \pm 0.78$ & $0.38 \pm 0.73$ \\
\hline Fibers $(\%)$ & $21.11 \pm 0.82$ & $33.10 \pm 0.75$ \\
\hline Moisture (\%) & $74.36 \pm 0.32$ & $78.76 \pm 0.41$ \\
\hline
\end{tabular}

* Average values calculated in triplicates

Table 5 - Physical-chemical characterization of the dehydrated bagasses of guava (Psidium guyava) and cashew (Anacardium ocidentali, L).

\begin{tabular}{l|rr}
\multicolumn{1}{c|}{ Parameters } & \multicolumn{2}{c}{ Natural bagasse } \\
\cline { 2 - 3 } & \multicolumn{1}{c}{ Guava } & \multicolumn{1}{c}{ Cashew } \\
\hline $\mathrm{pH}$ & $4.05 \pm 0.42$ & $3.82 \pm 0.51$ \\
Acidity (g ac citric/100g of the sample) & $1.64 \pm 0.23$ & $2.68 \pm 0.31$ \\
Soluble solids (oBrix) & $22.0 \pm 0.51$ & $2.68 \pm 0.31$ \\
Reducing sugars (mg/100g) & $20.22 \pm 0.31$ & $13.32 \pm 0.30$ \\
Total sugars (mg/100g) & $33.51 \pm 0.32$ & $16.86 \pm 0.28$ \\
Proteins (\%) & $2.28 \pm 0.39$ & $3.25 \pm 0.31$ \\
Lipids (\%) & $1.03 \pm 0.40$ & $1.3 \pm 0.39$ \\
Fibers (\%) & $37.74 \pm 0,21$ & $41.53 \pm 0.24$ \\
Moisture (\%) & $2.83 \pm 0.18$ & $3.55 \pm 0.20$ \\
\hline
\end{tabular}

* Average values calculated in triplicates

The results of the physico-chemical analysis of the guava and cashew natural and dehydrated bagasse are shown in Tables 4 and 5. The bagasse were collected from different lots and were homogenized to form a single lot. Natural bagasse of guava and cashew had $\mathrm{pH}$ values lower than 4.5 , consequently they were considered acidic food products (Stumbo, 1973).

This acidity provides a greater stability thus making it difficult for the growth of microorganisms, although it does not totally avoid food deterioration by fungus or bacteria during the food processing (Senai, 2000). The values of little high $\mathrm{pH}$ relating the dehydrated bagasse (Table 5) were in guava, and little less in cashew. These values corresponded to the ones obtained by Lima (2001). The acidity (\%ac. citric) found in natural bagasse of guava and cashew was higher than that found by Medina (1978).

The natural bagasse of guava showed a higher content of soluble solids than that in the cashew bagasse. Lima (2001) found $10.66{ }^{\circ}$ Brix content in the cashew bagasse, which lower than the value was obtained in this work. Concerning the guava bagasse, no data was found in the literature for comparison. A lipid content of $1.26 \%$ was observed by Lima (2001) in natural cashew. However, in this work rather lower values were observed for both types of natural bagasse. Protein contents could not be compared because of the lack of data in the literature. The values of the fibers bagasse of natural guava and cashew were 21 and $33 \%$, respectively, thus indicating that the fruits were in a good maturation stage (Miguel, 1999). The percentage of raw fibers in the dehydrated bagasse were usually much more higher when compared to those found in some products described in the literature.

The results obtained for the coliform, mould and yeast in natural cashew and guava, and in dehydrated bagasse were negative. 
The kinetic behavior of the cashew was similar to that of the guava, despite the higher drying speed used for the cashew. In both cases, a heating period was initially noted, however after 30 minutes, the rate decreased.
The results of the granulometric analysis of the dehydrated and triturated (in a multiprocessor) bagasse of cashew and guava are shown in Tables 6 and 7 , respectively.

Table 6 - Granulometric analysis of the dehydrated bagasse of cashew

\begin{tabular}{|c|c|c|}
\hline \multirow[t]{2}{*}{ Granulometric Range Tyler } & \multicolumn{2}{|c|}{ Bagasse retained } \\
\hline & (g) & $(\%)$ \\
\hline$<48$ & 103.23 & 43.61 \\
\hline$-48+65$ & 54.44 & 22.99 \\
\hline$-65+100$ & 25.95 & 10.96 \\
\hline$-100+250$ & 44.8 & 18.96 \\
\hline$-250+400$ & 1.72 & 0.72 \\
\hline$>400$ & 0 & 0 \\
\hline
\end{tabular}

Table 7 - Granulometric analysis of the dehydrated bagasse of guava

\begin{tabular}{l|c|c}
\hline \multirow{2}{*}{ Granulometric Range Tyler } & \multicolumn{2}{c}{ Bagasse retained } \\
\cline { 2 - 3 } & $(\mathbf{g})$ & $(\boldsymbol{\%})$ \\
\hline$<20$ & 43.74 & 18.37 \\
$-20+28$ & 28.69 & 16.84 \\
$-28+35$ & 40.11 & 16.84 \\
$-35+48$ & 57.22 & 24.03 \\
$-48+65$ & 33.14 & 13.92 \\
$-65+100$ & 22.52 & 9.46 \\
$-100+250$ & 4.40 & 1.84 \\
$>250$ & - & - \\
\hline
\end{tabular}

The particles retained in the sieves ranging from 65 to 100 mesh were considered as the most suitable ones to be added to the food product. The selection was based on the sensorial test since these particles were considered the best ones by the judges because they did not present any sandy feeling.

In the sensorial analysis the cookies enriched with dehydrated bagasse of guava and cashew in the concentration of $0,5,10$ and $15 \%$ were denominated as $\mathrm{A}, \mathrm{B}, \mathrm{C}$, and $\mathrm{D}$, respectively. These were evaluated for their appearance, color, odor, flavor and texture. The results of the variance analysis showed that there were significant differences among the cookies using different concentrations of cashew and guava dehydrated bagasse.
The samples of the cookies with 0,5 and $10 \%$ of dehydrated guava bagasse were accepted by the judges with R.A. > 70\%, with the exception of attribute texture in the case of the samples containing $10 \%$ of dehydrated bagasse. The samples with $15 \%$ of the dehydrated bagasse were not accepted, since they had R.A. $<70 \%$ (Fig. 3). The cookies having the concentrations of dehydrated bagasse of cashew were accepted (R.A. > 70\%) by the judges, although the one without the addition of dehydrated bagasse have showed higher values in all the attributes (Fig. 4).

In Fig. 5, the appearance of the cookies enriched with the dehydrated bagasse of guava and cashew is shown. 


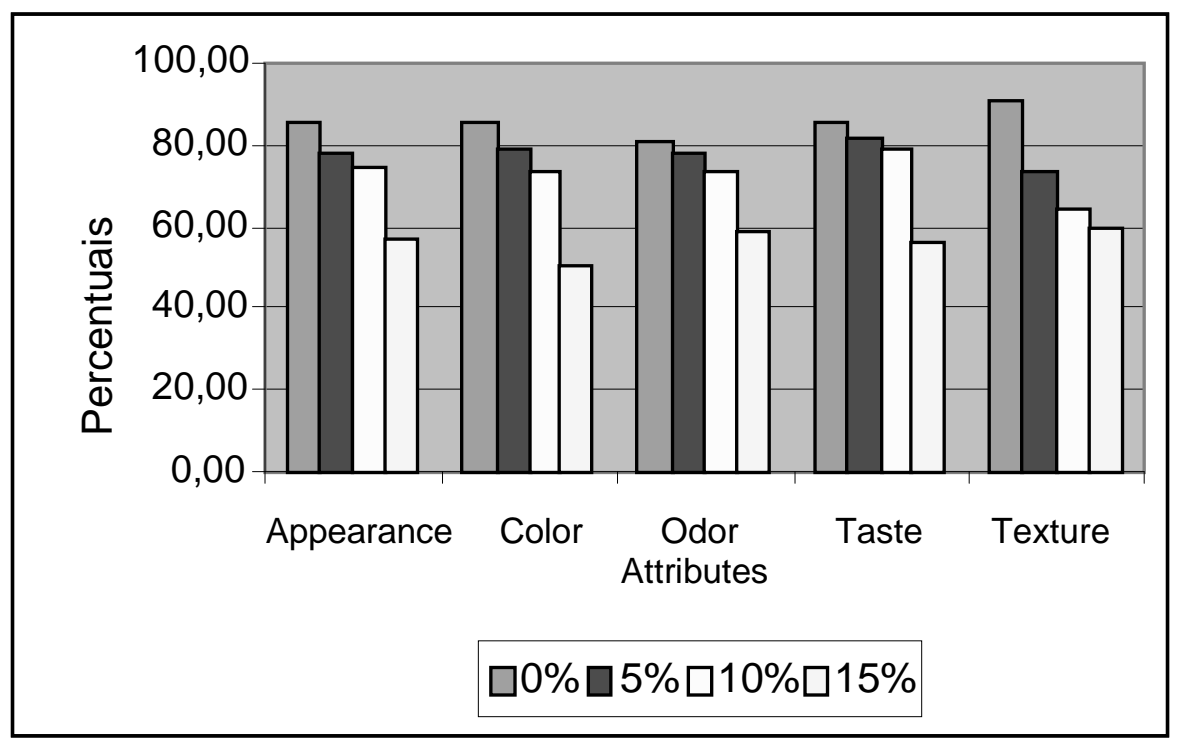

Figure 3 - Acceptability rate (A.R.) of the cookies with dehydrated guava (Psidium guayava) bagasse.

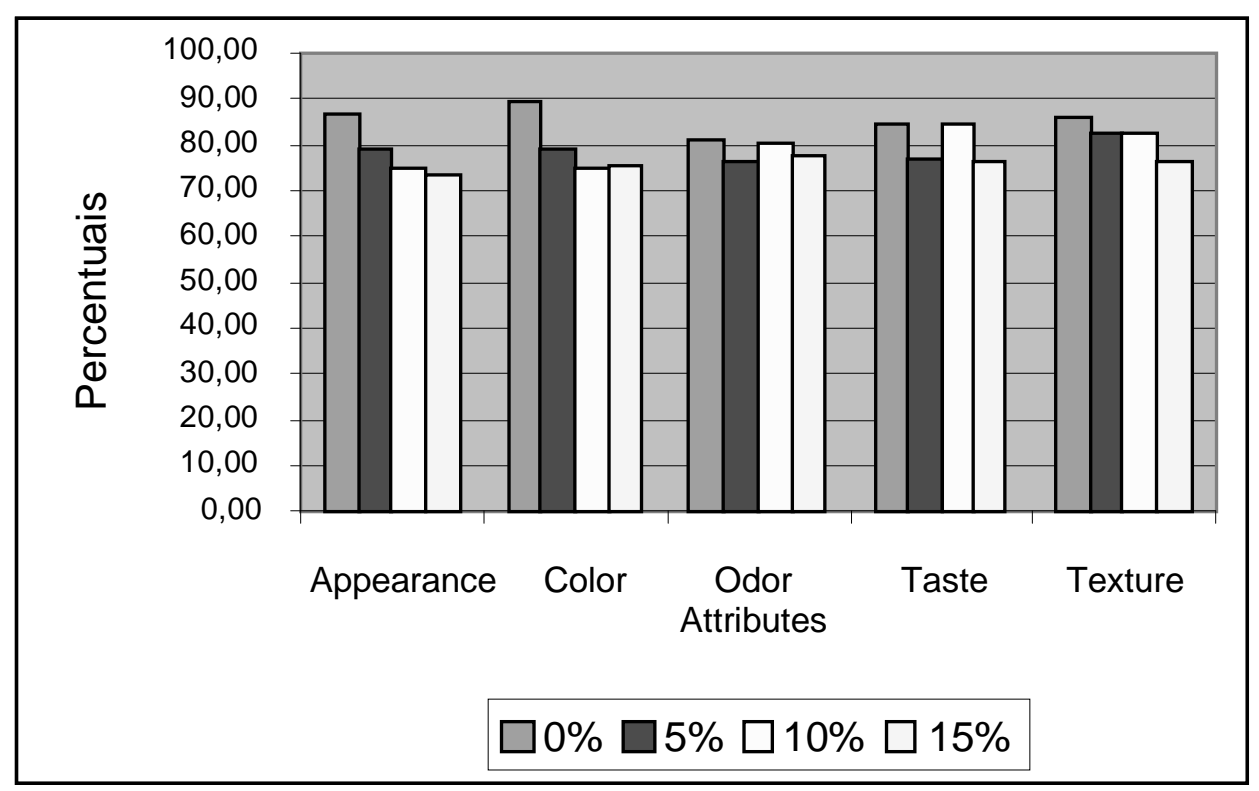

Figure 4 - Acceptability rate (A.R.) of the cookies with the cashew (Anacardium ocidentale, L.) bagasse. 


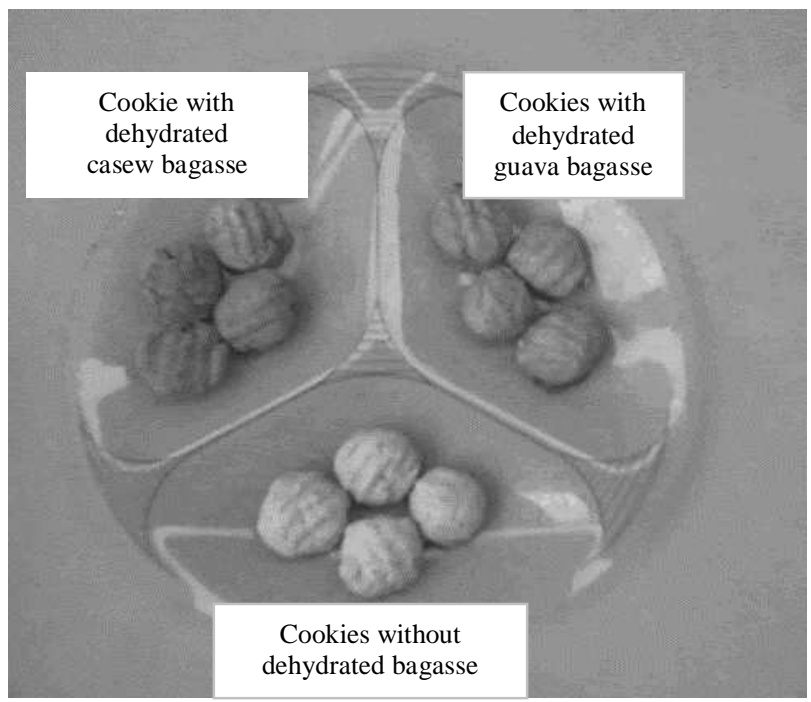

Figure 5 - Cookies enriched with dehydrated guava (Psidium guyava) bagasse and dehydrated cashew (Anacardium ocidentale, L.) bagasse, as well as cookies without the addition of the dehydrated bagasse.

\section{ACKNOWLEDGEMENTS}

The authors acknowledge the Programa de PósGraduação em Engenharia Química -UFRN (PPGEQ) and the Conselho Nacional de Desenvolvimento Cientifico e Tecnológico (CNPq)

\section{RESUMO}

Foi realizado o estudo de secagem dos bagaços de caju e de goiaba, visando sua utilização no enriquecimento de biscoitos. Determinou-se pH; sólidos solúveis, acidez total titulável, proteína, lipídios, fibras, cinzas, umidade e açúcares redutores e redutores totais. Foram realizadas também as contagens de coliformes totais e fecais e de bolores e leveduras. Adicionou-se aos biscoitos bagaços desidratados de caju e goiaba em percentuais de 5,10 e $15 \%$. Os atributos avaliados nos biscoitos com e sem adição de bagaços desidratados foram aparência, cor, odor, sabor e textura. Os resultados da caracterização físicoquímica foram coerentes com os da literatura consultada. As partículas retidas das peneiras entre 65 e 100 mesh foram consideradas as mais adequadas a serem incorporadas ao alimento. As formulações com $10 \%$ de bagaço desidratado de caju e 5\% de bagaço desidratado de goiaba apresentaram os maiores índices de aceitabilidade com relação ao sabor, $84,9 \%$ e $81,8 \%$, respectivamente.

\section{REFERENCES}

Borges, S.; Martins, K. A. and Silva, M. S. (1999), Utilização dos frutos de jatobá-do-cerrado (hymenaea stigonnacarpa mrt.) e jatobá-da-mata (hymenaea stilbocarpa mart.) na elaboração de biscoitos com reduzido teor de açúcares e alto teor de fibra alimentar. Ciência e Tecnologia de Alimentos, 19, 21-30.

Burkitt, D. P.; Walkera.R. and Painter, N. S. (1972), Effeect of dietary fibre on stools and the transittimes, and its role in the causation of disease.; Lancet, 2, 1408-1412.

Franco, B. D. G. M. and Landfraf, M. (1996), Microbiologia dos alimentos. São Paulo : Atheneu. $182 \mathrm{pp}$.

Lima, M. L. (2001), Estudo do aproveitamento de bagaço de frutas tropicais, visando a extração de fibras. Dissertação de Mestrado. Programa de Pósgraduação em Engenharia Química, Universidade Federal do Rio Grande do Norte, Natal - RN.

Medina, J. C.; Bleinroth, E. W. and Bernhardt, L. W. (1978), Goiaba da cultura ao processamento $e$ comercialização. Campinas : ITAL. 106 pp. (Série Frutas Tropicais; 6).

Medina, J. C.; Bleinroth, E. W. and Bernhardt, L. W. (1978), Caju da cultura ao processamento $e$ comercialização. Campinas : ITAL. 178 pp. (Série Frutas Tropicais; 4). 
Miguel, N. G.; Gorisnstein, S. and Belloso, O. M. (1999), Characterization of peach dietary fiber concentrate as food ingredient, Food Technology Department, Spain: University of Leida.

Normas Analíticas do Instituto Adolfo Lutz. (1985), Métodos químicos e físicos para análise de alimentos, São Paulo : Instituto Adolfo Lutz. 533 pp.

Protzek, E. C.; Freitas, R. J. S. and Waszcznskyj, N. (1998), Pães de forma elaborados com fibras de bagaço de maçã. In: Congresso Brasileiro de Ciência e Tecnologia de Alimentos, 16., Rio de Janeiro, Brasil. Anais... Rio de Janeiro.

Senai (2000), Elementos de apoio para o sistema APPCC. In: Qualidade e Segurança Alimentar, Brasília. $371 \mathrm{pp}$.

Speck, M. L. (1976), Compendium of methods of the microbiological examination of food, A.P.H.A. $1219 \mathrm{pp}$.

Teixeira, E.; Meinert, E. M. and Barbetta, P. A. (1987), Análise sensorial de alimentos., Ed. da UFSC, Florianópolis. 1219 pp.

Turano, W. et al. (1999), Estimativa de consumo diário ideal de fibra alimentar para população adulta. In: Simpósio Latino Americano de Ciência de Alimentos, 3., Campinas, São Paulo, Brasil. Anais... Campinas. 